\title{
Model Development on Awareness of Education for Sustainable Schools Development in Malaysia
}

\author{
Hanifah Mahat, Yazid Saleh, Mohmadisa Hashim and Nasir Nayan \\ Received: 3112 2015 / Accepted: 1403 2016 / Published online: 30062016 \\ (c) 2016 Faculty of Geography UGM and The Indonesian Geographers Association
}

\begin{abstract}
This article aims to develope the Structural Equation Model (SEM) on Education for Sustainable Development (ESD) student awareness around Sustainable Schools in Malaysia. The cluster sampling technique was used in selecting the school samples and the respondents were then also selected through simple random sampling among upper secondary pupils. A questionnaire survey was administered for 447 pupils, to evaluate the after effects of the SLAAS. The results showed that the model has been developed to provide an overview of each construct (knowledge on SLAAS Program, ESD content knowledge, ESD practices knowledge, attitudes of ESD and behavioral constructs of ESD) formed a fit model. The implication of this article showed that SLAAS Program implemented in Malaysia can be an indicator for the achievement of sustainable school.
\end{abstract}

Keywords: Education for sustainable development, Awareness, Knowledge, Attitude, Behavioral

\begin{abstract}
Abstrak Artikel ini bertujuan untuk membangun model persamaan struktur (SEM) kesadaran pendidikan pembangunan lestari (ESD) pelajar yang berada di Sekolah Lestari (SLAAS) di Malaysia. Teknik sampel berkelompok digunakan dalam memilih sampel sekolah dan responden kemudian juga dipilih melalui persampelan random sederhana di kalangan murid-murid menengah. Kuesioner telah dijawab oleh 447 murid untuk menilai kesan setelah program SLAAS dilaksanakan. Hasil kajian menunjukkan bahwa model yang dibangun menyediakan gambaran keseluruhan tiap konstruk (pengetahuan Program SLAAS, pengetahuan ESD, pengetahuan praktik ESD, sikap ESD dan konstruk tingkah laku ESD) yang membentuk model 'fit'. Implikasinya, artikel ini menunjukkan bahwa Program SLAAS yang dilaksanakan di Malaysia dapat menjadi indikator dari pencapaian sekolah lestari.
\end{abstract}

Kata kunci: Pendidikan pembangunan lestari, Kesadaran, Pengetahuan, Sikap, Tingkah laku

\section{Introduction}

Sustainability is a main agenda of the world. UNESCO [2010] has taken the initiative to implement the Decade of Education for Sustainable Development 2005-2014 (DefSD). Even the sustainability efforts of sustainable development has become a common agenda in many agencies, such as government agencies, non-governmental agencies and private agencies to increase knowledge and awareness of issues related to sustainable development. Basically, the concept of sustainable development, explains that, development is carried out to meet the needs of the current world's population without compromising the needs of future world population [WCED, 1987]. Awareness of the importance and the need for information regarding environmental issues has led to more initiatives taken by related organizations to initiate sustainable development programs for various target groups. Sustainable development is seen as one of the most modern development ideas proactive and practical to address the development needs as well as conservation of the environment [Fien, 1995; Hopkins \& McKeown, 2002; Huckle, 2009; Hazura, 2009; Joshi, 2009; Moroye, 2005; Sterling, 2004; Scoullos \& Malotidi, 2004]. Hanifah Mahat, Yazid Saleh, Mohmadisa Hashim and Nasir Nayan Geography \& Environmental Department, Faculty of Human Sciences, Universiti Pendidikan Sultan Idris, Malaysia Email: hanifah.mahat@fsk.upsi.edu.my
The world began to worry about the exploitation issue of the environment, economic growth and deterioration in quality of life [Omar, 2005]. In fact, unplanned development activities and neglecting the environmental aspects are also threatening the needs of the next generation. There is no question to how serious this situation is and how it will have an impact on survival, sustainability, civilization and prosperity [Laily, 2009].

An increase in understanding and awareness of the environment are two important elements in building the national capacity towards sustainable development [Dimitrova, 2014; Yeoh, 2005] Sustainable education is capable of generating changes in the mentality of the community in improving the quality of life [Firth \& Smith, 2013; Lampa, Greculescu \& Todorescu, 2013]. In Malaysia, study revealed that students who receive early exposure in the field of environmental education has failed to show awareness and commitment to environmental issues, in which the overall is still at a low level [Aini, Laily \& Sharifah, 2009; Arba'at, Kamsiah \& Susan, 2009; Fatimah, Norliza \& Salhayatin, 2011; Zohir, 2009]. Therefore, this study attempts to develop a Structural Equation Model on awareness of Education for Sustainable Development for students in an effort to promote "whole school approach" to expose to this sustainability. 


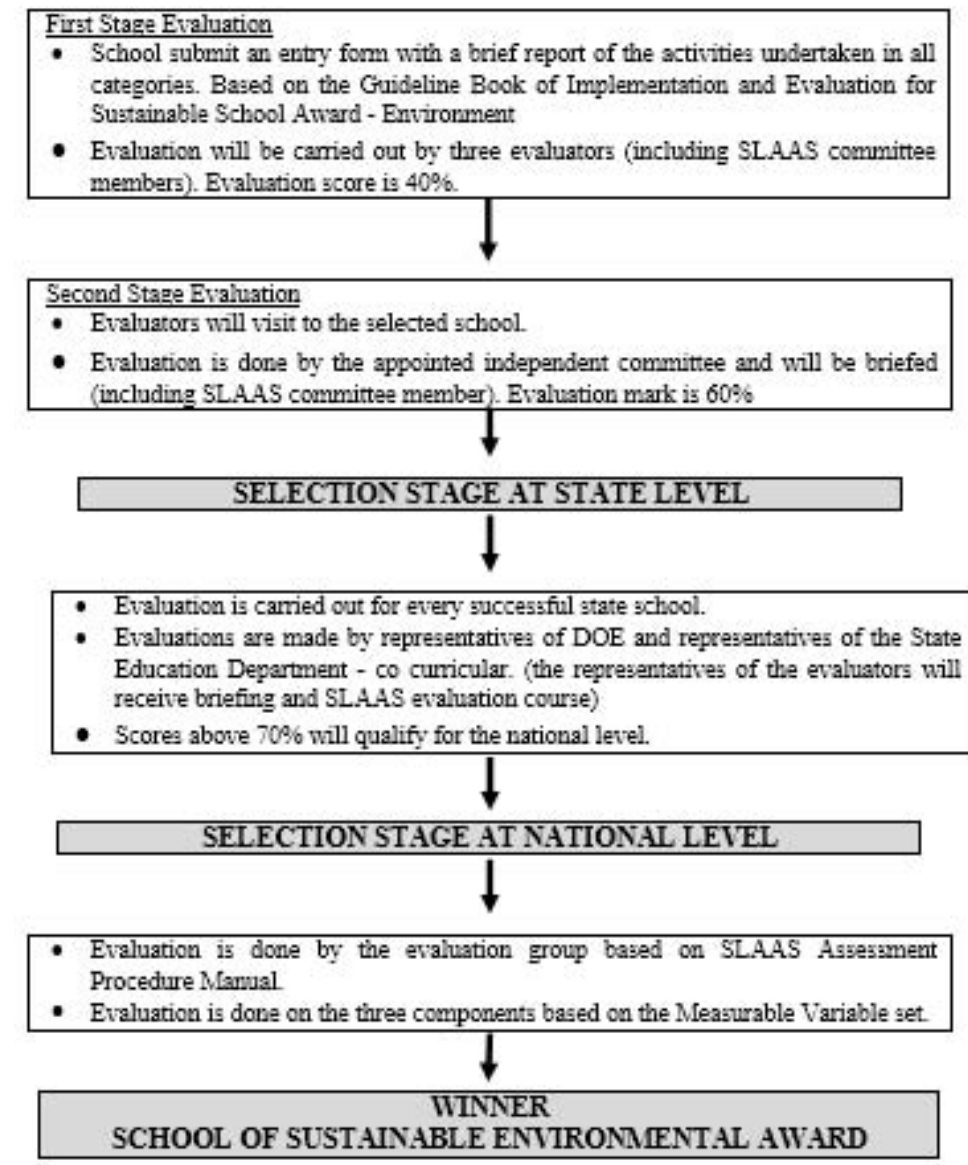

Figure 1. The process of SLAAS winner evaluation.

There are many definitions and interpretations given to explain the concept of Education for Sustainable Development (ESD). Definition given by UNESCO through Monitoring \& Evaluating Decade of Education for Sustainable Development, refers to a process of learning (or teaching approach) based on the principles that underlying sustainability at all levels and forms of education [UNESCO, 2009]. Geiser [2006]pointed out that ESD should involve components consisting environmental awareness towards ecosystem and natural resources, importance and limitations, the threat of human activities on ecosystem and building the skills of monitoring, analysis and involvement.

Education for sustainable development also refers to learning that is needed to maintain and improve the quality of life for future generations [Ghani \& Aziah, 2007]. Rohaty [2005] defines ESD as a way towards a better life for the present generation and the future. It is a dynamic process that requires each individual recognizing their own potentials and improving the quality of life. Zohir [2003] saw ESD as an educational mission to find a balance between human welfare and economic development with cultural traditions and respect for natural resources. Mazlin [2004] defines ESD as learning to understand human interaction with the environment and how the environment is managed wisely and responsibly towards sustainability of life on Earth. This process involves education about sustainable development, through sustainable development and for sustainable development.

Realizing education plays an important role in the development of society towards equality and sustainability, the United Nations launched the Decade of Education for Sustainable Development (DefSD) in 2005. DEfSD goal for the period of 2005-2014 is to integrate the principles, values and practices of sustainable development into all aspects of education and learning. The concept has been reemphasized during Born Declaration [UNESCO, 2009] in which ESD is a new direction for education and learning for all. It promotes quality education to everyone based on values, principles and practices necessary to respond effectively to current and future challenges. Thus, it is expected that educational efforts will encourage behavioral changes that will create a more sustainable future in terms of environmental integrity, economic viability and community for present and future.

The relationship between sustainable development and ESD is for identifying the priorities of teachers and students to address the three main elements environment, economy and social. Huckle [2013] describes the role of school in spreading knowledge, developing culture and harnessing the potential or the talent of students through school programs. Although environmental education can occur anywhere, but the basic and main place is in the school. School play an 


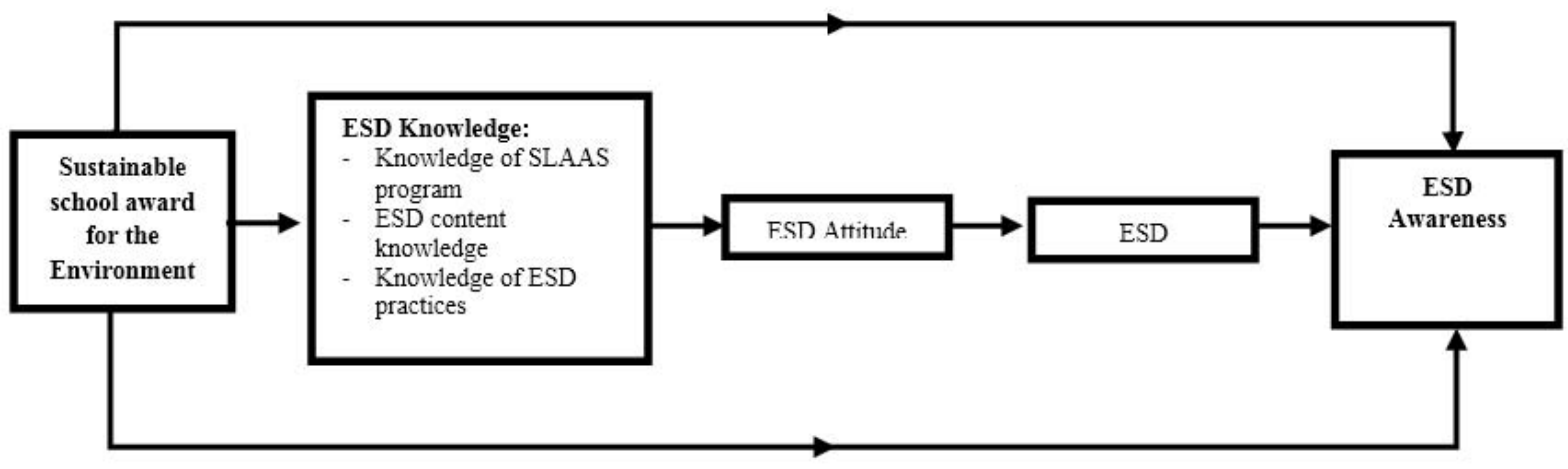

Figure 2. Framework model of ESD awareness.

important role in the process of helping students to learn and aware of the environment [Heneger, 2005; Mageswary, Zurita \& Norita, 2013], in fact study by Bergulnd, Gericke and Rundgren [2014] also found that the implementation of ESD in school affect students. When good values are instill in children, the development of the children will grow in line with the cultivation of environmental values that will ultimately produce environmentally concerned and responsible citizens [Hidayah et al., 2013].

In Malaysia, the implementation of sustainable school is a planned and structured program designed to promote sustainability among students. The program, so called Sustainable School Environment Award (SLAAS), has been implemented since 2005 and is open to primary, as well as secondary schools (not made compulsory by the Ministry of Education). The purpose of SLAAS was to create a school environment that fosters the conservation and preservation of the environment in the aspects of management, curriculum, co-curriculum and continuous green activities in order to establish a life practice in line with the concept of sustainable development. The SLAAS Program has been implemented in the form of competition, and at the end of each session (2 years for each session), there will be winners in the categories of primary and secondary schools. There is a screening to select the winner for the SLAAS Award, which is screening for the SLAAS participation level, state level and national level (see Figure 1). Three parties who monitor the implementation of this program are (i) the Curriculum Division, Ministry of Education; (ii) the Department of Environment, Ministry of Natural Resources and Environment, and (iii) the Institute of Environment and Development (LESTARI), Universiti Kebangsaan Malaysia.

\section{Conceptual framework study}

There are two interrelated theories underlying this study which is (i) Theory of Reasoned Action TRA developed by Fishbein and Ajzen [1975]. This theory has proposed three general concepts which are purpose, attitude and subjective norms in shaping behavior. According to this theory, the behavior of an individual is determined by his purpose / intention and also driven by the attitude. Basically TRA puts the knowledge element that forms attitude in conjunction with subjective norm and the subsequent behavior. Next (ii) Theory of Planned Behavior, TPB [Ajzen, 1991], which is the development of the TRA, has suggested four basic concepts which are belief (knowledge or insight), attitude, recommendation and behavior. TPB emphasizes on recommendations for action which is influenced by the belief (knowledge or insight) and also attitude. Both of these theories underlying the conceptual framework study in which knowledge has an impact on attitude and subsequently creating behavior. But this study is not only to review the domain knowledge, attitude and behavior, but also added three domain knowledge, namely knowledge of the program, ESD content knowledge and knowledge of ESD practices that are included as a measurement tool for ESD awareness.

The models in the study of environmental behavior change that also underlying the study are Conceptual Model ofEnvironmentalBehavior proposed byBarr, Ford and Gilg [2003], Model System of Behavioral Changes by Ramsey and Rickson [1976], Model of Responsible Environmental Behavior by Hines, Hungerford and Tomera (1986/87) and Model of Environmental Behavior by Hungerford and Volk [1990]. Through Conceptual Model of Environmental Behavior by Bar et al. [2003], in changing behavior it involves three variables, (i) environmental value variables (individual orientation towards the environment and the public view towards natural resources) (ii) situation variables (context / place, socio-demographic and knowledge / experience) and (iii) psychological variables (altruism variable, intrinsic motivation, perception, subjective norms, environmental threats, self-efficacy, and citizenship). Researchers adjust the model of this study by looking at the environmental value which is measured against ESD knowledge ie knowledge on SLAAS program, content knowledge about the concept 
of ESD and knowledge of ESD practices done

The situation variable in this study also involves context which is location of the school (SLAAS in urban and rural area) and the participation of the school in SLAAS Program (entry level, state level and national level), indirect socio-demographic and experience in implementing environmental activities or ESD activities. Psychological variable involved is in the context of the attitude which is cognitive, affective and psychomotor. Cognitive behavior involving belief, knowledge, or one's evaluation towards an object, affective attitude or emotion is one's feeling towards an object and psychomotor behavior is behavior or action taken by any person based on his belief and feeling. Attitude as agreed by most researchers Maarof [2001] Ramsey and Rickson [1976], Trandis [1971], Tonglet, Phillips and Read [2004], that attitude is an action that is not translated through action / behavior. The main conclusion of this model is the intention to behave is influenced by situation factor and psychology and finally forming the behavior.

The second guide in developing the conceptual framework is based on Model System of Behavior Change that was presented by Ramsey and Rickson (1976). This model is based on the linear development of environmental knowledge that leads to concern and environmental awareness. But according to Matthews and Riley [1995], the acquisition of knowledge does not necessarily change attitude and changes in attitude are not necessarily going to change the behavior. Hwang, Kim, and Jeng [2000] also reckon that, the increase in knowledge and awareness does not always lead to proenvironmental action. This study uses both opinions as a basis to see to what extend these facts are evident in the study of ESD awareness through this SLAAS Program.

Next, in confirming the presence of knowledgebehavior relationship in the context of environment, this study also places the Model of Responsible Environmental Behavior by Hines et al [1986/87], as a guide. Through this model, the emphasis is on knowledge variable and skill to encourage the individual to act in the direction of responsible behavior towards the environment. One's desire to act positively is also driven by the desire which is attitude towards the environment. The main summary of this model is the attitude (desire) will affect individual to gain knowledge before acting. This model emphasizes attitude between personality factors that is in line with knowledge factor to influence behavior.

Model of Environmental Behavior by Hungerford and Volk [1990] is also used as the basis of the study. This model puts the three stages of behavior change which is the entry level, ownership level and ownership level to develop responsible citizens of environmental behavior. The main emphasis of this model is towards the knowledge in each level so it will have an impact on behavior. The position of attitude domain is only as ancillary variable in the entry level. Based on theories and models derived from previous studies, a summary has been established in which putting the behavior domain as the final act of an individual who is molded or produced through knowledge and attitudes. In fact, in the context of SLAAS program, basically all programs and activities have to emphasis on knowledge because it is expected to influence attitude that ultimately expressed in the form of actual behavior. In fact, some of the SLAAS activity is those that involve outside of classroom area. In the context of this study, it is expected that teachers with knowledge will affect the attitude towards SLAAS program and influence the students to behave in line as well as students with knowledge of ESD through SLAAS activities will influence the attitudes and subsequently change the behavior.

\section{The Methods}

Analysis of structural equation modeling (SEM) is used to identify variables that influence awareness of Education For Sustainable Development for students. A total of 447 students from 12 schools that participated in the Sustainable School Award for the Environment (SLAAS) program were made respondents of the study. A cluster sampling technique were used in this research. The purpose of this study is to develop Structural Equation Model on awareness of Education For Sustainable Development for students in Sustainable School cluster. Quantitative study has been used by using questionnaire.

\section{Research instrument}

The questionnaire developed for this study is based on literature highlights on the topic of sustainable development, ESD, environmental education and mainly from questionnaire set based on previous studies that are common, stable and robust and similar to this field of research. In this study, face validity and content validity is done in advance before constructed validity process is done. Questionnaire for students is divided into six main parts. Part I involves the background of the respondents. A total of 11 items for Knowledge of SLAAS Program variables are constructed based on the Basic Formation of Sustainable School Award for the Environment [DOE, 2012a] also Guidelines on Implementation and Evaluation of Sustainable School Award for the Environment [DOE, 2012b]. For content knowledge variable, there is a total of 20 items that dismantle the ESD Content Knowledge. The items constructed are in accordance with the items that have been built through the study by Suriati [2009], and some items constructed by the researcher based on literature review. For ESD Practice knowledge variables, the construction of the items is based on The Implementation of SLAAS Program Handbook [Department of the Environment, 2004a] and also Guidelines on Implementation and Evaluation of Sustainable School Award for the Environment [DOE, 
2004b]. Questions involving the ESD knowledge source acquired either through the curriculum, co-curricular or other sources. Next, the ESD attitude variable comprises 20 items constructed from modifying items from the study of Norshariani [2009] and most items developed by the researcher based on literature review. Finally, the ESD behavior variable totaling 18 items. Improvements made after the items' first pilot and second pilot study done.

Internal consistency reliability test puts a variety of value / instrument reliability index. The ideal Cronbach Alpha coefficient is 0.70 above [Pallant, 2010]. Based on statistical analysis, the value of Cronbach Alpha for all constructs of ESD awareness has more than 0.6 degrees of reliability and is acceptable (Table 1).

Table 1. Value of Reliability for Actual Study of Students' Questionnaire Items

\begin{tabular}{lrc}
\hline Construct & $\begin{array}{c}\text { Student } \\
\text { Item } \\
\text { No }\end{array}$ & $\begin{array}{c}\text { Alpha } \\
\text { Cronbach } \\
\text { Value }\end{array}$ \\
\hline $\begin{array}{l}\text { Knowledge on SLAAS } \\
\text { Program }\end{array}$ & 11 & 0.701 \\
ESD Content Knowledge & 20 & 0.799 \\
ESD Practice knowledge & 10 & 0.821 \\
ESD Attitude & 20 & 0.87 \\
ESD Behavior & 18 & 0.872 \\
\hline
\end{tabular}

Structural Equation Model (SEM) test using Analysis of Moment Structure (AMOS version 22) was used to see the relationship between the dependent variable (variable endogenous) and independent variable (variable exogenous). The model consists of a variety of statistical techniques such as path analysis, confirmatory factor analysis, causal model with latent variable, analysis of variance and multiple linear regression model. SEM is the latest approach that is able to test the empirical model simultaneously. It involves various methods of statistical tests to review the influence of knowledge, attitude on behavior.

The data were also analyzed using AMOS (Analysis of Moments Structure) software version 18. In this study, SEM is used as a tool to identify whether there is a relationship between the dependent variables (variable endogenous) and independent variables (variable exogenous) in the model proposed by the researcher and whether it's true among respondents of the survey. This multivariate technique combining aspects of multiple regression and factor analysis to estimate a skill of related dependents that interrelates simultaneously [Hair, Anderson, Tatham \& Black, 1998, Joreskog \& Sorbom, 1993, Kelloway, 1998]. The standard beta value (standardized regression Coefficient) will serve as a guide to see significant levels of relationship of each construct and then to accept or reject the hypothesis.
Through SEM it can identify whether the pattern fit the model by using SEM guideline which are Goodnessof-fit index (GFI), Comparative-fit-index (CFI), the normalized-fit index (NFI) and Root Means Square Error of Approximation (RMSEA). SEM combines the concept of multiple regression analysis and path analysis (involving more than one relationship between the dependent variable and independent variable in the model).

\section{Result and Discussion}

Table 2 shows the profile of the 154 respondents (34.5\%) from the schools that are not going to the state level, 163 (36.5\%) of respondents from the SLAAS state participants and 130 people $(29.1 \%)$ were respondents at national level. Based on gender, a total of 309 were female respondents $(69.1 \%)$ and a total of 138 were male (30.9\%). From that amount there were 262 respondents aged 16 years $(58.6 \%)$ and respondents aged 17 years that makes a total of 185 people $(41.4 \%)$.

Table 2. Profile of Survey Respondents

\begin{tabular}{llll}
\hline Category & Sub Category & $\mathrm{N}$ & $\%$ \\
\hline Level of Partici- & SLAAS participants & 154 & 34.5 \\
pation & SLASS State & 163 & 36.5 \\
& SLAAS National & 130 & 29.1 \\
\multirow{3}{*}{ Gender } & Female & 309 & 69.1 \\
& Male & 138 & 30.9 \\
Age & 16 Years Old & 262 & 58.6 \\
& 17 Years Old & 185 & 41.4 \\
\hline N=447 persons & & &
\end{tabular}

Further discussion involves the correlation test. Before deciding the model to be built in structural equation test, correlation test between two variables must be done. This is necessary to see significant connectivity index between variables. Next, to see the model study, some results of the statistical tests of structural equation has to be discussed, namely, test fit the structural equation model, the estimated regression weights and the standard value of direct effects and indirect effects model.

Based on Table 3 it shows the relationship between the students ESD awareness variable. The study found that there is a relationship between SLAAS knowledge with ESD behavior $\left(r=0.137^{\star *}, \mathrm{P}<0.05\right)$, knowledge of SLAAS with knowledge of ESD practices $(\mathrm{r}=.111$ *, $\mathrm{P}<0.05)$, knowledge of SLAAS with ESD content knowledge $\left(\mathrm{r}=05388^{* *}, \mathrm{P}<0.05\right)$ and knowledge of SLAAS with ESD attitude $\left(\mathrm{r}=0538{ }^{* *}, \mathrm{P}<0.05\right)$. Similarly, ESD behavior with knowledge of ESD practices $\left(r=0587^{\star}, \mathrm{P}<0.05\right)$, ESD attitude with ESD behavior $\left(r=0.419{ }^{\star *} \mathrm{P}<0.05\right)$, ESD practical knowledge with ESD content knowledge $(\mathrm{r}=-0155$ * * $\mathrm{P}<0.05)$, knowledge of ESD practices with ESD attitude 
Table 3. Relationship Among Students ESD Awareness Variable

\begin{tabular}{lrrrr}
\hline & ESD Behavior & ESD Practice knowledge & ESD Content Knowledge & ESD Attitude \\
\hline Knowledge of SLAAS & $.137^{\star *}$ & $.111^{\star}$ & $.538^{\star *}$ & $.231^{\star *}$ \\
ESD Behavior & & $.587^{\star *}$ & -0.059 & $.419^{\star *}$ \\
ESD Practice knowl- & & & $-.155^{\star *}$ & $.236^{* \star}$ \\
edge & & & $.240^{\star *}$ \\
ESD Attitude & & &
\end{tabular}

$\left(\mathrm{r}=0236^{* *} \mathrm{P}<0.05\right)$, ESD attitude with ESD behavior $(\mathrm{r}=0.240 * * \mathrm{P}<0.05)$. However, the study found no significant relationship between ESD behavior with ESD content knowledge $(r=-0059 \mathrm{P}>0.05)$.

\section{Structural equation model fit test}

Figure 3 shows model development on awareness of education for sustainable development by using flow-analysis. The result of the study found that the indication on the overall model study have met the suggested value (recommended value). Thus the model study is fit with the data observed and has produced fit model index value RMSEA $=0.047$ as suggested by Hair, et al. [2006]; Kline [1998] and Arbuckle [1995] which is root means square error of approximation (RMSEA) $<0: 10$. Other indices have also been used to assess the suitability of the model namely chi-square / degree of freedom $\leq 2.0$, Goodness-of-fit index (GFI), TuckerLewis Index (TLI) and the adjusted goodness of fit index (AGFI) that is needed to produce an index $\geq 0.90$ [Hair et al., 2006; Kline 1998; Arbuckle and Wothe 1995]. Based on this study, it is found that index value for DF $=1.0 \leq 2.0, \mathrm{GFI}=0.996, \mathrm{TLI}=0.980$ and $\mathrm{AGFI}=0.973$ (Figure 2). Thus, the suggested model for constructs of ESD awareness (knowledge of SLAAS program, ESD content knowledge, knowledge of ESD practices, ESD attitudes and ESD behavior) is fit based on data that is observed to build the model development on awareness of education for sustainable development.

\section{Estimation value of the regression weight path analysis model}

Table 4 shows the results of students' measurement model using structural equation model test at the probability level of $\mathrm{p}<0.05$. It is found that all variables significantly affected except knowledge of SLAAS on ESD attitude $(\beta=-0.70)$ showed no significant relationship. This explains that the knowledge of SLAAS against ESD attitude does not give significant contribution.

\section{The standard value of direct effect and indirect effect model}

The SEM approach can estimate standard direct effect, standard indirect effect and total standard effect between independent variable, intermediate variable and variable bound, as well as the connectivity between variables with the variable domain of a model. Table 5 shows the results of the analysis of the standard direct effects, standard indirect effects and total standard effect of knowledge of SLAAS, ESD content knowledge, knowledge of ESD practices, ESD attitudes and ESD

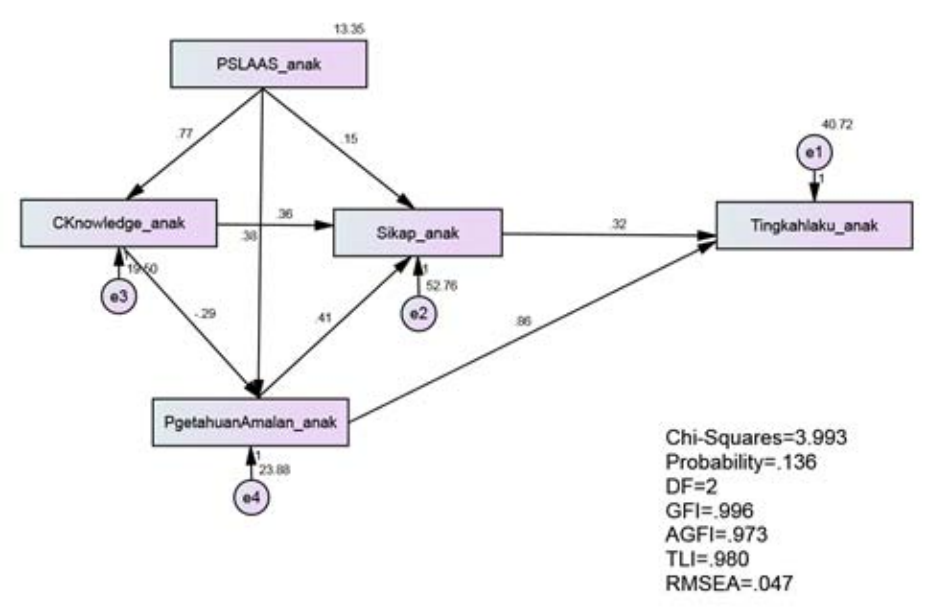

PSLAAS_anak $=$ Knowledge on SLAAS program PegetahuanAmalan_anak = ESD Practice knowledge CKnowledge_anak = ESD Content Knowledge Sikap_anak =ESD Attitude Tingkahlaku_anak =ESD Behavior

Figure 3. Model development on awareness of education for sustainable development 
Table 4. Results Of Student's Measurement Model

\begin{tabular}{|c|c|c|c|c|c|c|}
\hline Variable & & Variable & Estimate & $\beta$ & C.R. & $\mathrm{P}$ \\
\hline ESD content knowledge & $<---$ & Knowledge on SLAAS & 0.771 & 0.538 & 13,462 & $* * *$ \\
\hline $\begin{array}{l}\text { Knowledge on ESD Prac- } \\
\text { tices }\end{array}$ & $<---$ & ESD Content Knowledge & -0.294 & -0.302 & $-5,605$ & $* * *$ \\
\hline $\begin{array}{l}\text { Knowledge on ESD Prac- } \\
\text { tices }\end{array}$ & $<---$ & Knowledge on SLAAS & 0.381 & 0.274 & 5,078 & $* * *$ \\
\hline ESD Attitude & $<---$ & Knowledge on PSLAAS & 0.15 & 0.07 & 1,304 & 0.192 \\
\hline ESD Attitude & $<---$ & Knowledge on ESD Practices & 0.408 & 0.266 & 5,803 & $* * *$ \\
\hline ESD Attitude & $<---$ & Content Knowledge & 0.364 & 0.244 & 4,516 & $* * *$ \\
\hline ESD Behavior & $<---$ & ESD Attitude & 0.321 & 0.297 & 8,063 & $* * *$ \\
\hline ESD Behavior & $<---$ & Knowledge on ESD Practices & 0.857 & 0.517 & 14,024 & $* * *$ \\
\hline
\end{tabular}

behavior. The result of the study found that knowledge of SLAAS $(\beta=-.070)$ have no significant direct impact on the ESD attitudes of students but the knowledge of SLAAS ESD $\left(\beta=.161^{\star}\right)$ has a significant indirect effect on ESD attitudes of students. These findings indicate that it doesn't mean the knowledge of SLAAS has no effect on the ESD attitudes of students, but it needs to go through the students' knowledge of ESD practices. This means that knowledge of SLAAS significantly affect ESD content knowledge $\left(\beta=.538^{*}\right)$ and then the ESD content knowledge has significantly contributed to the ESD behavior $\left(\beta=-.108^{*}\right)$. Similarly, ESD content knowledge $\left(\beta=.244^{\star}\right)$ has a significant direct effect on the ESD attitude but ESD content knowledge $(\beta=.-$. 080 ) has the indirect effect which is not significant for the ESD attitude. This explains ESD content knowledge $\left(\beta=-.108^{\star}\right)$ will provide a significant indirect effect on
ESD behavior which is ESD content knowledge has to go through ESD attitude to have a direct impact on the ESD behavior.

Next, student knowledge of ESD practices $(\beta=$ $.266^{*}$ ) against ESD attitudes showed significant direct effects. Similarly, knowledge of ESD practices $(\beta=.517$ *) against ESD behavior showed a significant direct effect, but the knowledge of ESD practices $(\beta=.079)$ showed insignificant indirect effects. This explains the knowledge of ESD practices against behavior of the students has to go through ESD attitude. Based on the findings of the standard direct effect and standard indirect effect value, it clearly reinforces the result of Structural Equation Model Test to develop ESD awareness model based on the influence of knowledge of SLAAS Program, ESD content knowledge, knowledge of ESD practices, ESD attitudes towards the ESD behavior.

Table 5. Standard Value of Direct Effect and Indirect Effect Model

\begin{tabular}{|c|c|c|c|c|c|}
\hline Variable & & Variable & $\begin{array}{l}\text { Direct Effect } \\
\text { Estimation }\end{array}$ & $\begin{array}{l}\text { Indirect Effect } \\
\text { Estimation }\end{array}$ & $\begin{array}{l}\text { Total Effect } \\
\text { Estimation }\end{array}$ \\
\hline $\begin{array}{l}\text { Knowledge on SLAAS } \\
\text { program }\end{array}$ & $\rightarrow$ & ESD Content Knowledge & $.538^{\star}$ & 0 & $.538^{*}$ \\
\hline $\begin{array}{l}\text { Knowledge on SLAAS } \\
\text { program }\end{array}$ & $\rightarrow$ & ESD Practice knowledge & $.274^{\star}$ & $-.162^{\star}$ & $.111^{\star}$ \\
\hline $\begin{array}{l}\text { Knowledge on SLAAS } \\
\text { program }\end{array}$ & $\rightarrow$ & ESD Attitude & 0.07 & $.161^{\star}$ & $.231^{\star}$ \\
\hline $\begin{array}{l}\text { Knowledge on SLAAS } \\
\text { program }\end{array}$ & $\rightarrow$ & ESD Behavior & 0 & $.126^{*}$ & $.126^{*}$ \\
\hline ESD Content Knowledge & $\rightarrow$ & Knowledge on ESD Practices & $-.302^{\star}$ & 0 & $-.302^{\star}$ \\
\hline ESD Content Knowledge & $\rightarrow$ & ESD Attitude & $.244^{*}$ & -0.08 & $.163^{*}$ \\
\hline ESD Content Knowledge & $\rightarrow$ & ESD Behavior & 0 & $-.108^{\star}$ & $-.108^{\star}$ \\
\hline ESD Practice knowledge & $\rightarrow$ & ESD Attitude & $.266^{*}$ & 0 & $.266^{*}$ \\
\hline ESD Practice knowledge & $\rightarrow$ & ESD Behavior & $.517^{\star}$ & 0.079 & $.596^{*}$ \\
\hline ESD Attitude & $\rightarrow$ & ESD Behavior & $.297^{\star}$ & .000 & $.297^{\star}$ \\
\hline
\end{tabular}


Variables that serve as the independent variable and the intermediate in this model are the ESD content knowledge and knowledge of ESD practices. The result of this path analysis model showed that knowledge of SLAAS program has to go through the ESD content knowledge and next the knowledge of ESD practices to provide significant effect. ESD content knowledge variable has to go through knowledge of ESD practices to provide significant effect on ESD attitude. The next path analysis model is knowledge of ESD practices and then the ESD behavior.

Structural Equation Model test for the students gives an overview path of each construct that form a direct and indirect relationship model begins with the knowledge of SLAAS Program, ESD content knowledge, knowledge of ESD practices, ESD attitudes and ended with ESD behavior construct. This explains that in order to change the behavior of individuals as suggested by previous researchers [Ramsey and Rickson 1976, Hines et al., 1986/87; Kollmuss and Agyeman 2002], knowledge should be given earlier to give effect to attitude and thereafter can change the behavior. However, this study has added three domains of knowledge: knowledge of SLAAS program involving two sub-domains which is values and activities in SLAAS program, ESD content knowledge domain that covers three sub-domains namely environmental, economic and social. Finally, knowledge of ESD practices domain which consists of two sub-domains namely ESD practices in school and outside of school.

\section{Conclusion}

SLAAS program that was implemented in Malaysia for 2009/2010 session has put a measurable guide to measure the achievement of sustainable schools covering the field of management, co-curricular and greening. The focus of this study is in terms of ESD awareness domains. The production of the new Student Awareness Model of ESD saw action and route in term of psychology that has to be taken in the effort to provide ESD awareness to students. Thus, in the context of sustainable schools, it is an intellectual contribution to the parties involved to provide guidance towards creating ESD awareness. Even with the model study results of this study, it is a contribution of new knowledge in the context of ESD. Through the implementation in curriculum will expose students to various aspects of sustainability through everyday relationship with people, energy, materials and plants / animals in the school and outside the school. The implementations of ESD activities are not only through the theoretical input but also practical which gives more impact. Based on this study, it clearly gives the impression that the program has successfully met the fundamental objectives, and should be continued with some improvements or should be extended systematically. Directly or indirectly, it is a mechanism to help the nation through educational approaches to achieve sustainability in order to develop an understanding and love towards nature at an early age.

\section{References}

Ajzen, I. (1991). The theory of planned bahaviour. Organization Behaviour and Human Decision Processes. 50(2), 179-211.

Aini, M.S., Laily, P., \& Sharifah Azizah, H. (2009). Relevance between value,attitude prosocial behaviour and lifestyle. In. M.S.Aini, \& H.Sharifah Azizah, \& H.P. Laily, (Eds.), Sustainable Consumption: Between Reality and challenges (pp. 130-150). Serdang: Universiti Putra Malaysia.

Arba'at, Kamsiah, O., \& Susan, P. (2009). The Adults non formal environment education (EE) : A scenario in Sabah, Malaysia. World Conference on educational sciences 2009. Bangi: Universiti Kebangsaan Malaysia.

Arbuckle, J. L, \& Wothe, W. (1995). Amos 4.0 user's guide. Chicago, IL: SmallWaters Corporation. Chicago, IL: SmallWaters Corporation.

Barr, S., Ford, N. J., \& Gilg, A. W. (2003). Attitudes towards recycling household waste in Exeter, Devon: qualitative and quantitative approaches. Local Environment. 8(4), 407-421.

Berglund, T., Gericke, N. \& Rundgren,C.S.N. (2014). The implementation of education for sustainable development in Sweden: investigating the sustainability consciousness among upper secondary students. Research in Science and Technology. (In Press).

Dimitrova, E. (2014). The sustainable development concept in urban planning education: lessons learned on a Bulgarian path. Journal of Cleaner Production. 62, 120-127.

Fatimah, H., Norliza, S. \& Salhayatin, S. (2011). Income generation and student innovation in Environmental education: An Introduction. The 3rd National Convention Geography and Environment working paper. Organised by Geography and Environmental Department, Faculty of Humanities Sciences. Universiti Pendidikan Sultan Idris. Tanjong Malim. Perak, 8-10 February.

Fien, J. (1995). Environmental Education for a Sustainable Environment. Australia: Griffith University.

Firth, R., \& Smith, M. (2013). As the UN Decade of Education for Sustainable Development comes to an end: what has it achieved and what are the ways forward? The Curriculum Journal. 24(2), 169-180.

Fishbein, M., \& Ajzen, I. (1975). Belief, attitude, intention and behavior: An introduction to theory and research. Reading,MA: Wesley.

Geiser, K. (2006). Education for a transition to sustainability. Dlm. R. Forrant \& L. Silk (Eds.), Inside and out: Universities and education for sustainable development (pp. 29-40). Amityville, New York: Baywood Publishing Company. 
Ghani, A. A., \& Aziah, I. (2007). Strengthening Preparedness Education Sustainable Development by the Manager of School Education: A Case Study. Journal of Educational Management and Leadership. 17(1). http://www.iab.edu.my/jurnal.php (12 Mei 2012).

Hair, J.F, Anderson, R.E., Tatham, L., \& Black, W.C. (1998). Multivariate data analysis (5th. ed). New Jersey: Prentice Hall.

Hazura, A. B. (2009). Relationship between religious devotion, epistomoly and muslim student environmental knowledge and attitude and behaviour towards environment. Thesis $\mathrm{PhD}$. Universiti Sains Malaysia.

Heneger, E. (2005). Environmental education: A look at its pupose, methods and effectiveness. http:// web.centre.edu/estudies/Capstone Projects/ENS Henegar 2005.pdf (15 Februari 2012).

Hidayah, N. L. A., Haryati,S. \& Seow Ta Wee (2013). Parents involment towards Pupil's knowledge towards Environmental Awareness : A Preliminary Study Journal of Technology. 64 (1), 51-57.

Hines, J. M., Hungerford, H., \& Tomera, A. (1986/87). Analysis and synthesis of research on responsible environmental behavior: A meta-analysis. Journal of Environmental Education. 18(2), 1-8.

Huckle, J. (2009). Sustainable Schools: responding to new challenges and opportunities. Geography, 94(1), 13-21.

Huckle, J. (2013). Eco-schooling and sustainability citizenship: exploring issues raised by corporate sponsorship. The Curriculum Journal. 24(2), 206223.

Hungerford, H. R, \& Volk, T. L. (1990). Changing learner behavior through environmental education. Journal of Environmental Education. 21(3), 8-21.

Hwang, Y.H., Kim S, Jeng, J.M..(2000). Examining the causal relationships among selected antecedents of responsible environmental behaviour. Environmental Education. 31, 19-25.

Joreskog, K. \& Sorbom, D. (1993). Structural equation modeling with the SIMPLIS command Ž language. Hillsdale, NJ: Erlbaum.

Joshi, U. (2009). Education for Sustainable Development-The Role of University. International Forum of Teaching and Studies Marietta (pp. 6269).

Laily, P. (2009). Sustainable Use of Reality and Challenges. Serdang: Universiti Putra Malaysia.

Lampa, I., Greculescu, A., \& Todorescu, L.-L. (2013). Education for sustainable development - Training the young generation for the Future. Procedia Social and Behavioral Sciences, 78(120-124).

Kline, R.(1998). Principles and practices. New York: Guilford.

Kelloway, E. (1998). Using LISREL for structural equation modeling a researcher's guide. London: SAGE Publications.
Ma’arof, R. (2001). Social psychology. Serdang: Universiti Putra Malaysia.

Mageswary, K., Zurida, I. \& Norita, M. (2013). Preservice teachers' understanding and awareness of sustainable development concepts and traditional environmental concepts. Asia Pacific Journal ofEducators and Education. 28, 117-130.

Matthews, B. E., \& Riley, C. K. (1995). Teaching and evaluating outdoor ethics education programs. Vienna, VA: National Wildlife Federation. http://www.eric.ed.gov/PDFS/ED401097.pdf(18 November 2011)

Mazlin, M. (2004). Sustainable development: Implementation of Agenda 21. Planning Seminar Papers Agenda 21, Universiti Kebangsaan Malaysia, Bangi 11-12 November.

Moroye, C. (2005). Common ground: An ecological Perspective on teaching and learning. Curriculum and teaching dialogue. 7(1/2), 123-139.

Omar, O. (2005). Education for sustainable development: The roles of universiti as regional centre of expertise. Pulau Pinang: Universiti Sains Malaysia.

Ramsey, C. E., \& Rickson, R. E. (1976). Environmental knowledge and attitudes. Journal of Environmental Education. 8(11), 10-18.

Rohaty, M. (2005). Strategic Planning of Education for World Peace. The 5th Comparative Education Society of Asia Biennial Conference 2005. Bangi, Universiti Kebangsaan Malaysia.

Scoullos, M., \& Malotidi, V. (2004). Handbook on methods used in environmental education and education. Athens: MIO-ECSDE. http://www. medies.net/_uploaded_files/publications/ HANDBOOK._ENGpdf.pdf (18 Julai 2011).

Sterling, S. (2004). Higher education, sustainability and the role of systemic learning. In P.Blaze-Corcoran \& A.E.J.Wals (Eds.). Higher Education and the Challenge of Sustainability: Prolematics, promise and practice (pp 49-70). Dordrecht: Klumer.

Tonglet, M., Phillips, P. S., \& Read, A. D. (2004). Using the Theory of Planned Behaviour to investigate the determinants of recycling behaviour: a case study from Brixworth. UK. Resources. Conservation and Recycling. 41, 191-214.

Triandis, H. C. (1971). Attitude and attitude change. New York: Wiley.

UNESCO. (2009). Bonn declaration. UNESCO World Conference on Education for Sustainable Development. Bonn, Germany.

UNESCO. (2010). Education for Sustainable Development. http://www.unesco.org/education/ desd: (12 Mei 2011)

WCED (World Commission Environment and Development). (1987). Our common future. Oxford: Oxford University Press.

Yeoh, B.G. (2005). Education and environmental awareness in the Community Recycling Program Penang: Proceeding of the Bandar Lestari- 
Environment Award Ceremony. Marriott Hotel Putrajaya.

Zohir, M. A. (2003). Geography as a environmental education medium. Digest of Education. 3(2), 5160.

Zohir, M. A. (2009). Environmental education application in the teaching of Geography in secondary school: knowledge. efficacy attitude and teacher practice Malaysia. Thesis PhD. Universiti Kebangsaan Malaysia. 